\title{
Challenges in the Funding Model of State Universities of Sao Paulo
}

\author{
Helio Nogueira da Cruz ${ }^{1}$, Carlos Antonio Luque ${ }^{1}$, Alberto Teixeira Protti ${ }^{2}$ \\ ${ }^{1}$ Department of Economy, School of Economics, Business and Accounting, University of Sao Paulo, Sao Paulo, Brazil \\ ${ }^{2}$ Institute of Economics, State University of Campinas, Sao Paulo, Brazil
}

Email address:

hncruz@usp.br (H. N.da Cruz), cluque@usp.br (C. A. Luque), abprotti@usp.br (A. T. Protti)

\section{To cite this article:}

Helio Nogueira da Cruz, Carlos Antonio Luque, Alberto Teixeira Protti. Challenges in the Funding Model of State Universities of Sao Paulo. International Journal of Economics, Finance and Management Sciences. Vol. 3, No. 3, 2015, pp. 148-155.

doi: $10.11648 /$ j.ijefm.20150303.11

\begin{abstract}
This article presents an evaluation of the funding model of state universities in the State of Sao Paulo in a context of growing demand for high quality higher education, the improvement of the position of these universities in international rankings and the growth pressures on the budget of the educational sector of the State of Sao Paulo. Since 1989, the State Universities in the State of Sao Paulo have their revenues linked to the collection of the Tax on the Circulation of Goods and Services - ICMS (acronym in Portuguese). However, the universities have a major weakness in their revenues links, as these are established each year by the Budget Guidelines Law of the State.
\end{abstract}

Keywords: Higher Education Funding, State Universities Efficiency, Public Higher Education

\section{Introduction}

The debate on funding of higher education has increased in most countries, due to the increasing demand for higher education and the high pressure of social costs upon public budgets. The current stage is characterized by an increased search of resources connected to monthly fees or to research projects involving the private sector. (Johnstone, 2006; Jongbloed, 2008, among others). In Brazil these last two sources are small because of legal and bureaucratic or ideological issues.

The main objective of this paper is to evaluate the Financial Autonomy Model (FAM) and the challenges faced by the State Universities in the State of Sao Paulo - SUSPs (University of Sao Paulo - USP, University of Campinas UNICAMP and State University "Júlio de Mesquita Filho" UNESP).

In the first section we present the broader issues of the evolution of higher education in Brazil and in the State of Sao Paulo. In the second, we present some characteristics of the funding for higher education in Brazil and in the State of Sao Paulo. Finally there is a section that shows the main characteristics of the FAM and indicates some of the main challenges these institutions must face.

\section{Evolution of Brazilian Higher Education}

Higher education is a factor of crucial importance for sustainable economic growth over time. The development process consist in producing more goods with fewer productive resources and it depends on technological progress and increasing quality of human resources.

It is also known that education in general - and specifically higher education - promote more intense and rapid social inclusion processes, transforming society not only from an economic standpoint, but also by the promotion of social improvement.

In this way, educational services acquire the characteristics of a public good because their benefits reach all society and are not limited to those that can be individually internalized. In this case, it is justified the government involvement in the production or funding of goods that generate these externalities.

It is further claimed that the direct beneficiaries of this system, i.e. the students themselves should participate in the funding. This is because they appropriate a part of the benefits generated by education by the increase of the salaries they will receive. In the Brazilian case, another reason is added, namely 
the fact that a significant portion of students in public institutions of higher education come from families who have conditions to pay for their education.

The fact is that there was strong growth in the Brazilian higher education sector in recent years (Graph 1), mainly due to the development of undergraduate courses in the private sector. At the graduate level the expansion occurred mainly in public institutions (Table 1).

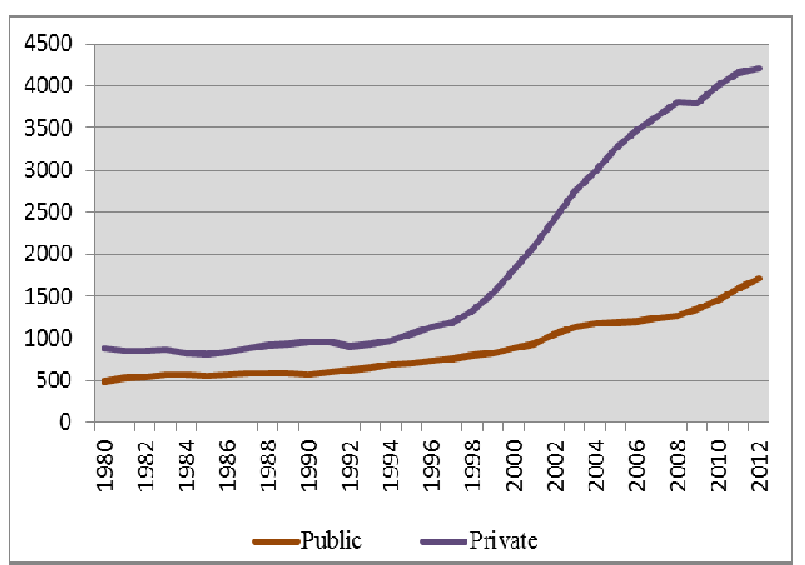

Sources: Map of Higher Education in the State of Sao Paulo - and SEMESP Census of Higher Education 2012 - MEC/INEP

Graph 1. Enrollment in Higher Education - Brazil (in thousands).

Table 1. Enrolment in Undergraduate and Graduate Studies in Brazilian Higher Education in 2012, according to their administrative category.

\begin{tabular}{lll}
\hline Administrative Category & Undergraduate & Graduate \\
\hline Public & $27 \%$ & $84 \%$ \\
Private & $73 \%$ & $15 \%$ \\
\hline
\end{tabular}

Source: Census of Higher Education 2012 - MEC / INEP

\section{Funding of Public Higher Education in Brazil}

During the inflationary process experienced by our economy, especially from the mid-70s on, some sectors started defending the so called budgetary linking as they believed that this strategy would be an appropriate mechanism for the protection of their resources. The concept of budgetary linking states that the budget of a particular sector should be based upon another nominal variable, usually the amount of taxes in general or a specific tax.

This strategy is correct when we take into consideration a country marked by serious economic and social problems that transform social demands, especially emergency ones - health and safety - into pressures upon public outlay and hence into a tight race for resources. The budgetary linking is more important for the sectors of economic and social activity that have no emergency connotation.

We can say that there are three challenges for funding public higher education:

\subsection{Education Versus Other Sectors}

During the drafting of the Brazilian Constitution (1988) it was clear that due to the financial weakness of the public budget the resources for education were insufficient to solve its demands. This happened because the impact of education in attending the economic and social problems is only observed in the long run and the educational sector does not present the urgency character.

In order to protect the educational sector, the Congress introduced in the Federal Constitution (1988) what we call budgetary earmarking. In the case of the educational sector, it says that the public sector must apply at least $25 \%$ of the taxes' revenue to basic and higher education. In the State of Sao Paulo, the State Constitution increased this percentage to $30 \%$.

Naturally, other sectors realized that a way to protect their resources was to establish a budget entailment. For instance, in the year 2000 the health sector also introduced this linking of resources. In 2012, a Federal Law established that States and municipalities must apply $12 \%$ and $15 \%$, respectively, of their taxes revenues to public health actions.

To give an idea of the implication of this process upon the budget, in the case of the State of Sao Paulo for each Real collected of the ICMS (a state value added tax) you should allocate 0.30 cents to the educational sector; 0.12 to the health sector; 0.13 cents to the public debt to maintain the payment of services; 0.01 cent to the Sao Paulo Research Foundation (FAPESP) to promote incentives for research activities; and around 0,02 to the social sector, specifically the housing sector. So for each Real collected we have approximately 80 cents already directed to specific sectors.

Because of the reduced flexibility that this kind of resource's earmarking bring to the budgetary process, nowadays there is a strong political pressure against all sort of budget entailment. So the first challenge for the funding of the educational sector is the pressure to curb the budgetary entailment. We can say that this is a dispute of resources between those sectors that have earmarked resources and those which do not have this entailment.

\subsection{Pressures Inside the Educational Sector}

Another source of pressures that affect the higher education system is located in the educational sector itself. To begin with, it is important to remember that the Brazilian Constitution says that public education in official schools has to be funded solely by the Government (at all different levels). That means that public universities and schools can not charge any kind of fee for their educational services.

With the universalization of basic education in Brazil we have observed a persistent decline of the public school quality. In order to reverse this situation it was created in 1996 by a Constitutional Amendment the Fund for Maintenance and Development of the Fundamental Education and Teaching Valorization (FUNDEF). The resources for this fund were constituted by $15 \%$ of almost all taxes and transfers revenues received by the states and municipalities, specially Value Added Tax on the Circulation of Goods and Services - ICMS (which represents near 90\% of taxes revenues of the State of São Paulo), States and Municipalities Participation Funds (mostly from collected income taxes which in Brazil is 
responsibility of Union), and total amount of other resources transferred by the Union.

In 2003, by another Constitutional Amendment, the FUNDEF was replaced by the Fund for the Maintenance and Development of Basic Education and Enhancement of Education Professionals (FUNDEB). This new fund was constituted by $20 \%$ of almost the same sources as the FUNDEF. So by this law the source of the funds for basic education was increased.

In the case of the State of Sao Paulo, since 1989 the Budget Guidelines Law says further that the Government will transfer to the three State Universities at least $9,57 \%$ of the ICMS revenue. ${ }^{1}$ However it is important to say that this law is weaker when compared to constitutional or federal laws.

So we have the following guidelines to structure the budget in the Sao Paulo educational sector: one based on the Brazilian Constitution, that says that the Government must apply at least $20 \%$ of the almost all taxes and transfers revenues to basic education (for our argument it is important to focus on the ICMS); one based on State Constitution, that says that the State must apply at least $30 \%$ of taxes revenues to educational sector; and one based on annual State law, that says that it should be applied at least $9.57 \%$ of the ICMS to the universities.

The educational sector in the State of Sao Paulo involves the secretary of education which is responsible for the basic education. The higher education system is constituted by the three public universities, some single faculties, and the Paula Souza Center, which is responsible for the technical schools (high school level) and the technology colleges (higher education level), the FATECs.

There is in Brazil an excess demand for almost all public services. In education we could say that at the basic level this excess is more related to the need of improving quality because Brazilian public school quality is very low. On the other hand, at higher level, the pressure for expansion is on the number of vacancies. So we can conclude that both these systems will put pressure for a higher volume of resources.

Naturally the universities are in a fragile situation because they must compete for resources within the educational sector. Certainly is not easy to convince the authorities and the society that higher education is more important than basic education.

\subsection{Pressures Inside Higher Education System}

Due to the excess demand for higher level education the government has consistently tried to expand the number of vacancies. However the difficulties it faced were very huge. One of the reasons is that universities have a relatively fixed structure for each unit. The structure is almost the same if we are talking about a school of Business, Engineering, Medical Sciences, etc. We associate to each expansion the same structure, which means that the university will have to provide research, learning and extension. Naturally, to expand

1 ICMS is a value-added tax that goes to the States of the Brazilian federation. vacancies in such a way is very expensive.

As soon as governmental authorities realized this situation they expanded the higher education system through the Paula Souza Center activities. To exemplify the situation we can analyze the distribution of resources in the educational sector during the period 2002/2012 as can be seen in Table 2 below (the amount of resources allocated is quoted in millions of Reais).

Table 2. Distribution of resources in the educational sector - 2002/2012.

\begin{tabular}{|c|c|c|c|c|c|}
\hline \multirow{2}{*}{ Item } & \multicolumn{2}{|l|}{2002} & \multicolumn{2}{|l|}{2012} & \multirow{2}{*}{$\begin{array}{l}\text { \% } \\
\text { Increase }\end{array}$} \\
\hline & RS million & $\%$ & RS million & $\%$ & \\
\hline $\begin{array}{l}\text { Net revenue of } \\
\text { taxes }\end{array}$ & 32,794 & - & 94,343 & - & 188 \\
\hline $\begin{array}{l}\text { Educational } \\
\text { sector }\end{array}$ & 9,866 & 30.1 & 28,697 & 30.4 & 191 \\
\hline $\begin{array}{l}\text { Secretary of } \\
\text { education }\end{array}$ & 6,932 & 21.1 & 20,317 & 21.5 & 193 \\
\hline Universities & 2,666 & 8.1 & 6,821 & 7.2 & 156 \\
\hline $\begin{array}{l}\text { Paula Souza } \\
\text { Center }\end{array}$ & 202 & 0.6 & 1,296 & 1.4 & 542 \\
\hline Others & 66 & 0.2 & 263 & 0.3 & 298 \\
\hline
\end{tabular}

Source: Development and Regional Planning Secretary of the State of Sao Paulo

The increase of the resources for the Paula Souza Center is significantly higher than that of the Universities. More recently the government decided to create another university, the so called UNIVESP ${ }^{2}$, which is responsible for long distance learning.

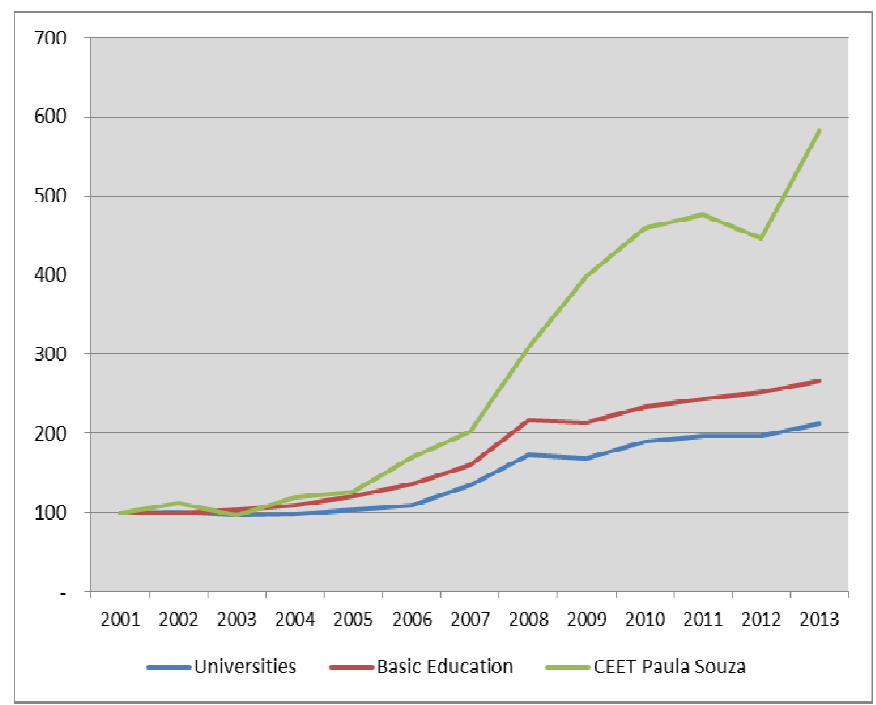

Source: State of São Paulo Treasury.

Graph 2. Real Growth Index of Financial Public Transfers to Educational Sector (2001-2013).

Finally, there are technical aspects that affect the relationship between budgets and the management of public activities. The traditional preparation of budgets relies heavily on information of production costs of services involving

2 Virtual University of the Sao Paulo State 
running costs and capital expenditure, and not in production or efficiencies indicators. Thus, funds are allocated for the payment of various operating expenses, such as personnel costs, various cost items, maintenance expenses as well as investment expenditures for the expansion of facilities, etc.

This form of budgeting is based on the functioning characteristics of public institutions as well as on principles of public accounting. Thus, similarly to a private company, in the publication of their balance sheets the emphasis is put is upon the different types of expenditure and not on efficiency or production indicators.

During the last years, because of the growth of budgetary earmarking, government agencies responsible for the drafting of public budgets have reacted to such links. It is argued that the linking crystallizes priorities over time, allocating resources automatically for certain areas, even though there are no structured projects. Thus, the budgetary earmarking would reduce the quality of public outlay. It is argued that excess linkings transform the budgeting process into a mere exercise for the allocation of resources previously defined without the traditional criteria for the allocation of funds to priority projects.

The result of these differing points of view generates a peculiar situation in which the establishment of a minimum level of resources to be applied, this threshold ends up turning into a maximum. The reaching of a percentage above the established minimum limits is not an easy task within the traditional mechanisms for the construction of the budget parts, because each additional percentage point will then require a very accurate detailing of the projects to be covered and goals to be achieved, as this increase implies percentage reductions of the sectors that do not have the budgetary earmarking.

\section{Funding of State Universities in the State of Sao Paulo}

Despite the growth of the Brazilian population aged 18 to 24 years old enrolled in higher education courses throughout the initial decade of this century, the results are unsatisfactory when compared with other countries. Between 2001 and 2010, the net enrollment rate increased from $8.9 \%$ to $14.1 \%$. In the State of Sao Paulo the rate increased between 2002 and 2010 from $9.7 \%$ to $18.4 \%$. The low insertion of youths aged 18 to 24 creates a pressure for a strong growth in the number of vacancies in institutions of higher education especially the public ones. It should be noted that a substantial portion of the growth in the number of vacancies in recent years was due to the growth of private educational institutions (Graph 3). Enrollment in higher education in the State of Sao Paulo evolved from 633 thousand in 2000 to 1,326 thousand in 2011 , an increase of $109 \%$. Again, private universities were the ones that grew the most.

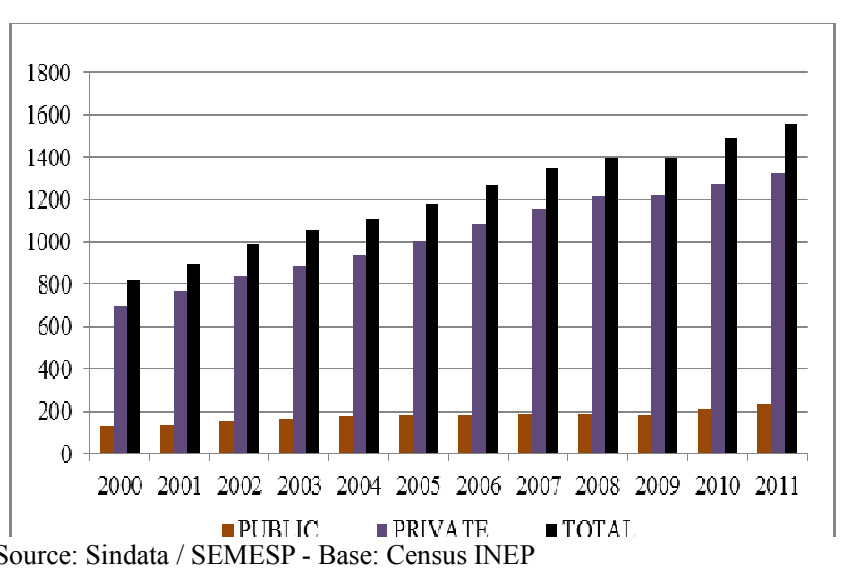

Graph 3. Enrollment in the State of Sao Paulo - 2000-2011.

It should be noted that the Federal Constitution in its Article 207 States that "The universities enjoy educational, scientific, administrative, financial and property management autonomy." The Constitution of the State of Sao Paulo establishes in its Article 253 that "the organization of the higher education system will aim at enlarging the number of school vacancies in public institutions, both in daytime and evening classes". In its Article 254 it establishes that "The autonomy of the university will be exercised, respecting the necessary democratization of education and public accountability of the institution." On the other hand in its Article 255 it establishes that "The State shall apply, annually, in the maintenance and development of public education, at least thirty percent of revenues resulting from taxes, including resources proceeding from transfers".

Thus, the educational sector in the State of Sao Paulo has three budgetary linkings. The broader one is dictated by the Federal Constitution, setting aside $30 \%$ of net tax revenue to finance maintenance and educational development actions. Additionally we have the linking to the FUNDEB, allocating $20 \%$ of tax revenues, and that of the universities, earmarking $9.57 \%$ of revenue of the ICMS. It should be again emphasized that the linking of basic education through the FUNDEB has a constitutional basis, while that of the university is based on an annual bill according to the Budget Guidelines Law.

The Financial Autonomy Model (FAM) was established by the State bill No. 29,598 of February 2, 1989, which stated that the State Universities in the State of Sao Paulo - SUSPs, would receive $8.4 \%$ of the ICMS collection - quota of the State in the reference month - for the implementation of their budgets. On the other hand, the universities would be responsible for all their expenses, including their inactive personnel and judicial writs of payments.

The monthly transfer of the ICMS percentage for the universities started to occur punctually since the establishment of FAM. Also attached to the FAM is the possibility to transfer funds between budget sub-paragraphs, the possibility to change their staff resources, the establishment of the careers of technical and administrative employees and faculty members, which ultimately allowed the flexible management of the universities. 
Each year, the Budget Guidelines Law (BGL) establishes the amounts to be transferred to the universities. These amounts increased from $8.4 \%$ of the ICMS in 1984 to $9.0 \%$ in 1992 and $9.57 \%$ in 1995.

The establishment of the State Universities budget based on a percentage of the ICMS revenue ensures increased revenue pegged to the growth of economic activities in the State of Sao Paulo (Table 3). From the moment this consolidates a budget process that ensures that growth, pressures are established for the expansion of services provided by these universities especially the creation of undergraduate vacancies.

On the other hand, the consolidation of the FUNDEB in raising the investment percentage from $15 \%$ to $20 \%$ increases the share of basic education in the $30 \%$ of the taxes revenue according to the State Constitution.

Additionally, the significant growth of the Paula Souza Center will begin to exert increasing pressure on the constitutional linking. In third place, the binding of State universities is weaker when compared to the linking of education as a whole for it is annually established by the Budget Guidelines Law. Fourth, the linking is made to the ICMS collection and not to the total of taxes collected. Depending on how the ICMS collection evolves in the sum of all taxes, this may imply in changes in the participation, especially when we remember that the ICMS collection is always the main fiscal war instrument.

Finally, as higher education expands, either by the expansion of State universities themselves, either by expansion of the Paula Souza Center, or other mechanisms that might be devised, such as the creation of the UNIVESP the result is that the $30 \%$ to be applied to the educational sector may be insufficient to take all such pressures in consideration.

This set of pressures will be more or less strong depending on the expansion of the State's economy leading to an increase in the collected taxes. Naturally, if the State's economy expands significantly, in such a way that the increase of the proceeds from this growth will permit to address all the pressures for expansion of higher education, there will be no major problems. However, if the growing needs of the sector demand an increase of resources in a greater proportion than that of the economic growth the situation of the educational sector budget gains enormous complexity. In this case, there are two alternatives. The pressure is accommodated by an expansion of the percentage applied, which will mean a greater dispute between the educational sector and other sectors, such as health, public safety, etc. or, alternatively, there will be an internal dispute in the educational sector itself, between basic and higher education.

Another dimension of the challenge for higher education funding is the fact that the budgetary linking of the State universities, besides being legally more fragile as it is defined by the Budget Guidelines Law, is backed only by the ICMS revenue.

\section{Evaluation of the Financial Autonomy Model (FAM) and the Challenges of the State Universities of the Sao Paulo State (SUSPs)}

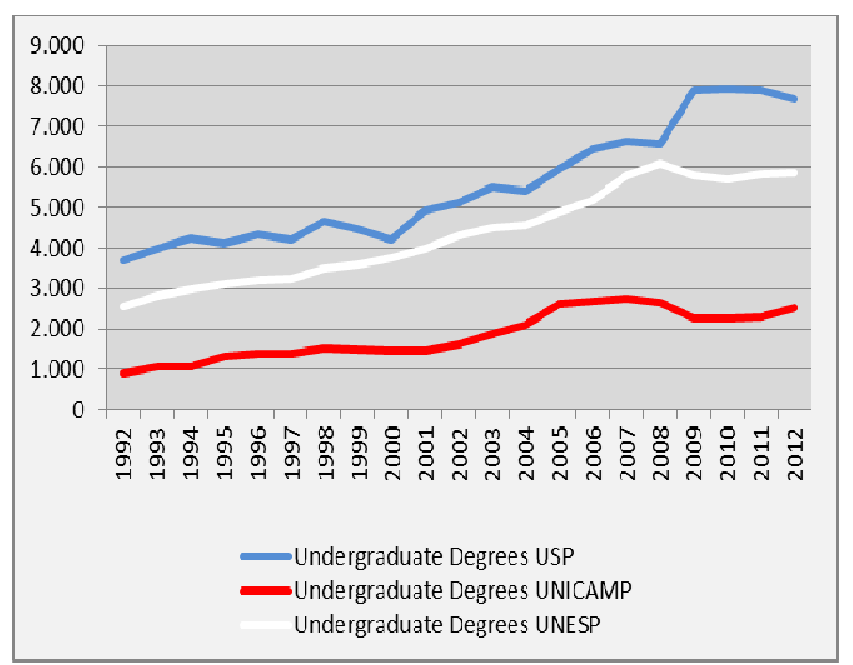

Sources: Statistical Yearbook of the SUSPs

Graph 4. Undergraduate Degrees in the SUSPS - 1992-2012.

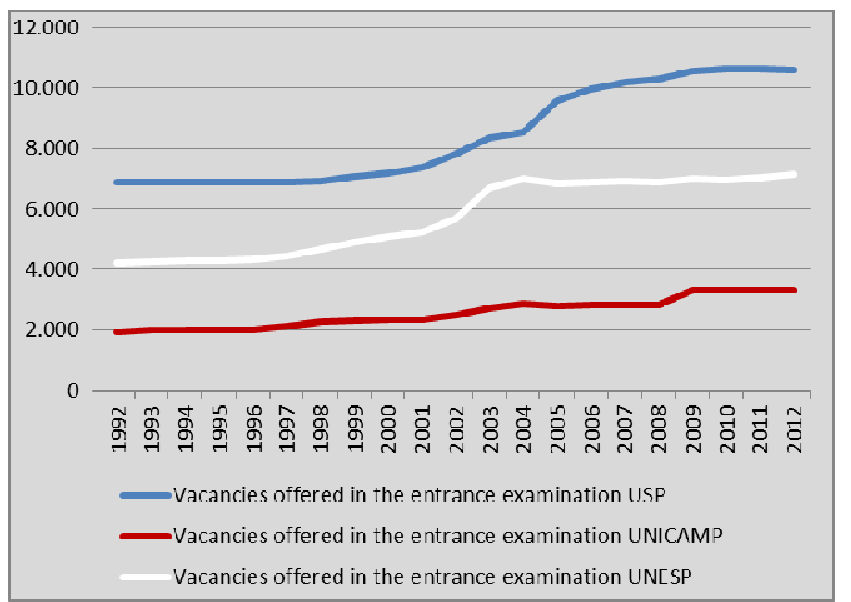

Sources: Statistical Yearbook of the SUSPs

Graph 5. Vacancies offered in the entrance examination of the SUSPS 1992 2012 .

The FAM was generally quite favorable for the core activities growth of SUSPs, as shown in the graphs below. Significant breakthrough occurred between 1992 and 2012 in the academic activities, with the growth in the number of the undergraduate degrees (125\%) (Graph 4) and strong expansion of the number vacancies offered (61\%) (Graph 5). Graduate studies advanced still further. There was a $264 \%$ increase of master's degrees and doctorates in the three universities (Graph 6). The scientific production, measured by papers published in indexed journals, has grown even more during this period (610\%) (Graph 7). The other core activities, especially in the areas of culture and extension also evolved substantially, although there are no good indicators in the international literature. The favorable position 
of SUSPs in international rankings of universities is another positive aspect of their evolution as shown in Table 3 below.

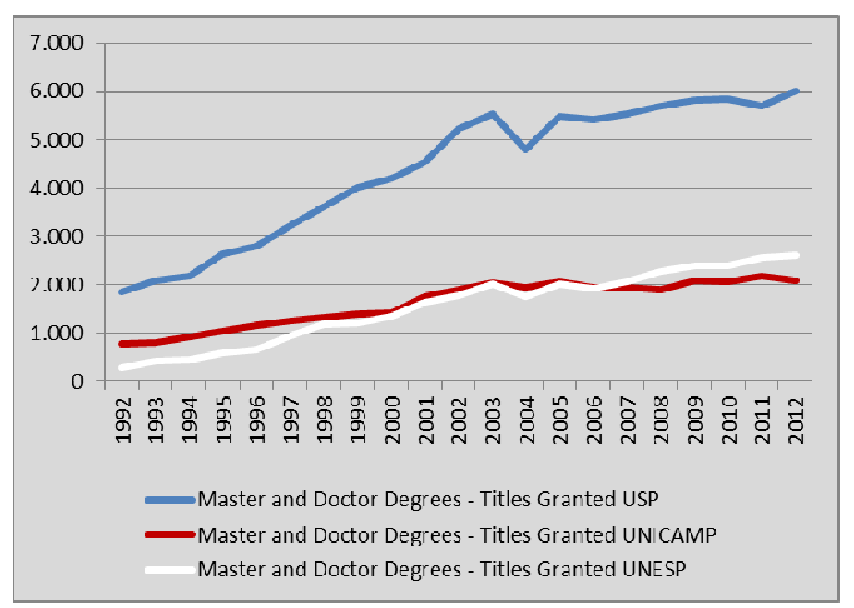

Sources: Statistical Yearbook of the SUSPs

Graph 6. Master and Doctor degrees - Titles granted in the SUSPS - 1992 2012

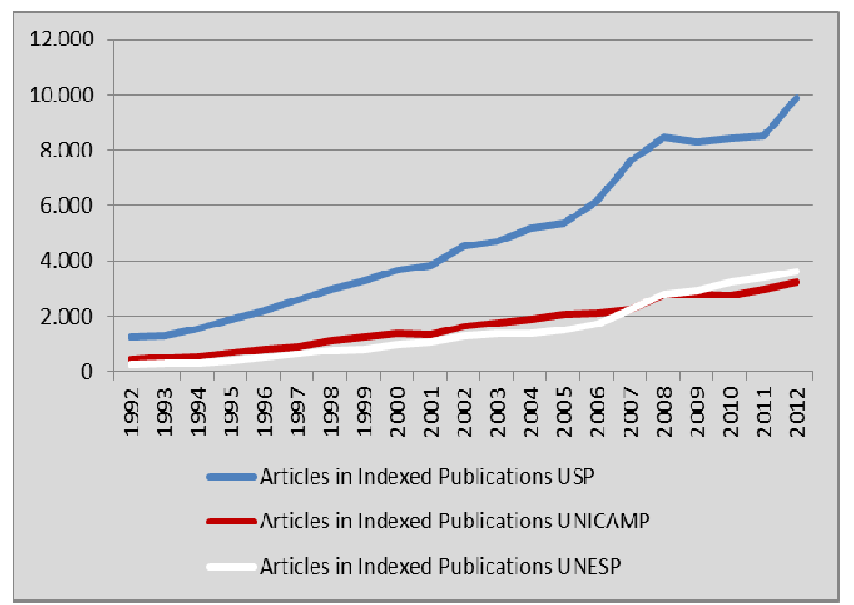

Sources: Statistical Yearbook of the SUSPs

Graph 7. Articles of the SUSPs in indexed publications -1992-2012.

Table 3. World University Rankings - 2013.

\begin{tabular}{lll}
\hline SUSPs & $\begin{array}{l}\text { QS World International } \\
\text { Ranking }\end{array}$ & $\begin{array}{l}\text { Shanghai World } \\
\text { International Ranking }\end{array}$ \\
\hline USP & $127^{\circ}$ & $101^{\circ}-150^{\circ}$ \\
UNICAMP & $215^{\circ}$ & $301^{\circ}-400^{\circ}$ \\
UNESP & $411^{\circ}-420^{\circ}$ & $301^{\circ}-400^{\circ}$ \\
& $Q^{\circ}$ International & THE - Times Higher \\
SUSPS & Ranking: BRICs & Education - Ranking BRICs \\
USP & $8^{\circ}$ & $11^{\circ}$ \\
UNICAMP & $10^{\circ}$ & $24^{\circ}$ \\
UNESP & $25^{\circ}$ & $87^{\circ}$ \\
\hline
\end{tabular}

In fact, the three universities are quite different in many aspects, including in their costs standards, especially in relation to the payroll. The graph 8 below shows that important changes occurred in their spending patterns over time. They are shown in a relational perspective, in relation to each other. The USP, which had the lowest involvement in 1995, appears in 2013 with the greatest linking of the resources transferred by the Treasury. These changes cause tensions between universities, which may lead to destabilization of the FAM.

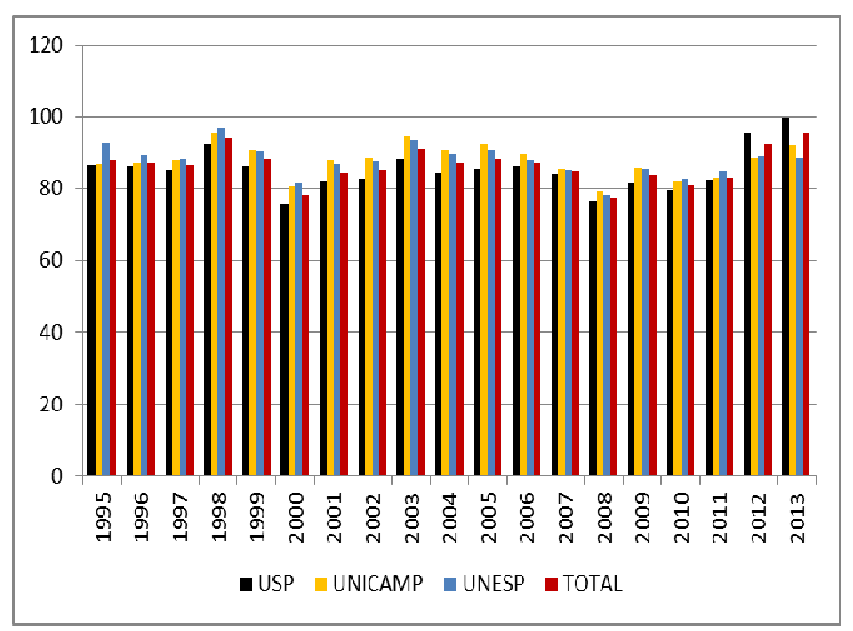

Graph 8. Financial releases bound to the payroll in the SUSPS - 1992-2012.

It is observed that the FAM has provided favorable conditions for the expansion of the activities of SUSPs and improvement of their quality.

In the case of oscillations of transfers arising from fluctuations of the ICMS, it was observed that, even with strong growth trend in the period, it was necessary in times of transfer decline to promote increases in the percentages of transferences from $8.4 \%$ to $9.0 \%$ and afterwards to $9.57 \%$. It should be noted that as the payroll is downward rigid in nominal terms in the Brazilian economy, it is difficult to make major adjustments in the accounts of universities in the low periods of the ICMS, especially when inflation is lower, as occurred after the Real Plan in $1994^{3}$.

As pointed out in another article ${ }^{4}$, the FAM has allowed greater stability in the real transfer of resources and, consequently, greater stability in the salaries and other expenditure and investment items of the SUSPs in periods of high inflation. On the other hand, with the inflation, the universities created a pattern of spending structured in real terms, i.e. adjusted for inflation, more flexible and favorable for the adjustment to any policy mistakes. These might especially include excess nominal adjustments that could possibly occur particularly in salaries upon which the law imposes downward rigidity.

The FAM has also stimulated the planning, review and transparency of the activities of SUSPs. The creation of a complex set of indicators, both academic and of other dimensions of activities - true management tools significantly contributed to the advancement of these universities.

The FAM is shown as a positive experience, but suffers from structural weaknesses. The public sector does not accept

\footnotetext{
3 The Real Plan of 1994 promoted a strong reduction in inflation and ushered in a new phase of Brazil's macroeconomic policy in force until today.

4 Book "The USP AND ITS CHALLENGES" - Chapter: "Autonomy and Financial Resources"
} 
easily the budgetary earmarking, as pointed out earlier, and has difficulties in accepting financial reserves made by the SUSPs, which are necessary to address low stages of economic cycles. The pressure to increase outlays and reduce financial reserves can become quite acute. The pressure for salary increases may also jeopardize the financial stability of SUSPs and if not properly balanced, can severely unbalance the accounts of the universities. The pressures within the budget were also significant and the linking protected the SUSPs at various times.

That is, even with expanding trend of transfer of funds, which has occurred in most of the period, it may occur that the FAM does not show itself to be stable enough to face economic fluctuations and the various types of internal or external pressure to which the SUSPs are subjected.

Note that the FAM does not mean sovereignty of the SUSPs, which must constantly engage in dialogue with the various organizations of the government and society to match their strategic positioning with the demands of society.

\section{Final Considerations}

As shown throughout the text, the experience of the so-called FAM brings important elements for discussion in public universities:

\section{a) Budgetary aspects}

From the budgetary standpoint, the linking of resources constitutes a way of ensuring that strategic goals (universities of quality) are implemented, so that they may be protected from short-term urgencies. The pressures within the budget between sectors of activities and types of services have been intense and the linking contributes to the stability of the funds transferred to the SUSPs.

The second aspect of this model of public management is that budgets usually deal with the costs to be financed, which ultimately put in the background aspects of production and efficiency of public services. With the FAM, government authorities do not control nor the costs or the products directly.

The adoption of the FAM requires that the SUSPs accumulate financial reserves in favorable times so that these resources may finance their costs in low phases of the economic cycle. To accept that these reserves have this role and do not mean a permanent slack of resources is a learning experience for government authorities.

b) Cycles and macroeconomic trends

The prolonged period of economic growth, and therefore of the ICMS and of resources transferred to the SUSPs, requires universities to grow in their various core activities. If this does not happen there will be excessive accumulation of reserves and shifting of the government and society needs, which in the long run, undermine the FAM itself.

The periods of oscillations of the GDP and transferences to the SUSPs must be alternated with the use of financial reserves, otherwise the FAM will not withstand the pressures associated with a period with excess resources and another period with their lack. The stability of the FAM depends crucially on this intertemporal management of resources.
Inflation also strongly influences the stability of the FAM. In periods of high inflation, SUSPs have more flexibility to adjust their payroll and preserve real wages (adjusted for inflation) than other public entities, noting that the legislation in force in the Country imposes the downward rigidity of salaries, since nominal salaries cannot be reduced.

c) Planning, evaluation, and rationality

The existence of the FAM allowed the improvement of the universities management by stimulating transparency, planning and evaluation. The creation of a system of indicators allowed the rationalization of several activities. The FAM has stimulated the efficiency of the universities.

State universities will have to set growth targets, especially of undergraduate education vacancies. Simultaneously they must seek alternatives for the expansion of these vacancies in less costly ways but maintaining quality.

The long-term partnership between the State Government and State universities requires dialogue, transparency and planning so that society - that in the last resort finances the State and consequently the universities - be attended to.

\section{References}

[1] AGHION, P., DEWATRIPONT, M., HOXBY, C., MAS-COLELL, A. and SAPIR, A. Higher aspirations: An agenda for reforming European universities. Brussels, Bruegel Blueprint Series, Volume V, 2008.

[2] BARR, N. Financing higher education in the UK: The 2003 White Paper. House of Commons Education and Skills Committee Post-16 student support, Session 2002-03, 2003.

[3] BARR, N. Higher Education Funding. Oxford Review of Economic Policy, v 20, n2, p 264-283, march 2004.

[4] CRUZ, H. N. Autonomia e Recursos Orçamentários do Estado. Chapter of the book A USP e seus Desafios: I Fórum de Política Universitária - Modules 2 and 3, Sao Paulo, 2001.

[5] JONGBLOE, B. Funding higher education: options, trade-offs and dilemmas. In: Full bright Brainstorms 2004 - New Trends in Higher Education, Lisbon, Portugal. September 24-25, 2014.

[6] JONGBLOE, B. Funding higher education: a view from Europe. Paper prepared for the seminar Funding Higher Education: A Comparative Overview, organized by the National Trade Confederation of Goods, Services and Tourism, CNC, Brasilia, October, 2008.

[7] LEPORI, B., BENNINGHOFF, M., JONGBLOE, B., SALERNO, C. e STIG, S. Changing patterns of higher education funding: evidence from CHINC countries. Article written to Changes in University Incomes: Their Impact on University-Based Research and Innovation (CHINC), November, 2005.

[8] MITCHELL, M., PALACIOS, V. and LEACHMAN, M. States Are Still Funding Higher Education Below Pre-Recession Levels, Center on Budget and Policy Priorities, May, 2014.

[9] PEDROSA, R. H. L. Um Plano Diretor para o Ensino Superior Público do Estado de Sao Paulo. Revista Ensino Superior Unicamp, Novembro, 2010. In: www.gr.unicamp.br/ceav/revistaensinosuperior/ed02_novembr o2010. 
[10] SCHWARTZMAN, J. O Financiamento das Instituições de Ensino Superior no Brasil. Instituto de Estudos Avançados da Universidade de Sao Paulo, 2004. In: http://www.iea.usp.br/tematicas/educacao/superior/autonomiaf inanciamento/schwartzmanfinanciamento.pdf. 